\title{
IMPLEMENTING CHARACTER EDUCATION IN MADRASAH
}

\author{
Syarnubi \\ UIN Raden Fatah Palembang \\ Jl. Prof.K.H. Zainal Abidin Fikri, KM 3.5 Pahlawan, Palembang, Indonesia, 30151 \\ Email: syarnubi@radenfatah.ac.id
}

\section{Firman Mansir}

Universitas Muhammadiyah Yogyakarta

Jl. Brawijaya, Tamantrito, Kasihan, Bantul, D.I Yogyakarta, Indonesia, 55183

Email: firmanmansir@umy.ac.id

\author{
Mulyadi Eko Purnomo \\ Universitas Sriwijaya Palembang \\ Jl: Srijaya Negara, Bukit Lama, Ilir Barat, Palembang, 30128 \\ Email: mulyadiekopurnomo@gmail.com
}

\section{Kasinyo Harto}

UIN Raden Fatah Palembang

Jl. Prof.K.H. Zainal Abidin Fikri, KM 3.5 Pahlawan, Palembang, Indonesia, 30151

Email: masyo_71@yahoo.com

\author{
Akmal Hawi \\ UIN Raden Fatah Palembang \\ Jl. Prof.K.H. Zainal Abidin Fikri, KM 3.5 Pahlawan, Palembang, Indonesia, 30151 \\ Email: akmalhawi_uin@radenfatah.ac.id
}

Received: 05, 2020. Accepted: 06, 2021. Published: 06, 2021

\begin{abstract}
This study investigated the application model of character education in Islamic Religious Education learning and spiritual extracurricular activities in Madrasah Aliyah Negeri 3 Palembang. Data were collected using participatory observation, in-depth interviews, and documentation. Data analysis was carried out through data reduction, data presentation, and conclusions. The results show that the implementation model of character education is a collaboration between the integration model and the supplement. Character education is collaborated through learning Islamic Religious Education and spiritual extracurricular activities. These two activities produce knowledge, attitudes, and moral actions on the part of students. The success of character education can be seen from the behavior of students who have religious behavior, honest, disciplined, responsible, caring, polite, cooperative, creative, hardworking, curious, friendly, and social care. There were some factors that supported the success of character education and they include religious programs, dormitories, and facilities. Meanwhile, the inhibiting factors for the success of character education were the negative influence of technology, limited supervision by madrasahs, and weak cooperation between madrasahs and parents of students.
\end{abstract}

Keywords: Model, Character Education, Culture

\footnotetext{
ABSTRAK

Penelitian ini mengkaji penerapan model pendidikan karakter dalam pembelajaran Pendidikan Agama Islam dan kegiatan ekstrakurikuler spiritual di Madrasah Aliyah Negeri 3 Palembang. Pengumpulan data dilakukan dengan observasi partisipatif, wawancara mendalam, dan dokumentasi. Analisis data dilakukan melalui reduksi data, penyajian data, dan penarikan kesimpulan. Hasil penelitian menunjuk.kan babwa model implementasi pendidikan karakter merupakan kolaborasi antara model integrasi dan suplemen. Pendidikan karakter dikolaborasikan melahi pembelajaran Pendidikan Agama Islam dan kegiatan ekstrakurikuler spiritual. Kedua kegiatan ini menghasilkan pengetabuan, sikap, dan tindakan moral di pihak peserta didik. Keberbasilan pendidikan karakter dapat dilihat dari
} 
perilaku peserta didik yang memiliki perilaku religius, jujur, disiplin, tanggung jawab, peduli, santun, kooperatif, kreatif, pekerja keras, rasa ingin tabu, ramah, dan peduli sosial. Ada beberapa faktor yang mendukung keberhasilan pendidikan karakter antara lain program keagamaan, asrama, dan fasilitas. Sementara itu, faktor penghambat keberhasilan pendidikan karakter adalah pengaruh negatif teknologi, keterbatasan pengawasan madrasah, dan lemabnya kerja sama antara madrasah dengan orang tua peserta didik.

Kata Kunci: Budaya, Model, Pendidikan Karakter

\section{INTRODUCTION}

Character education can be basically defined broadly as the act of giving and inculcation of positive values to students in the context of strengthening self-identity. It is an educational discourse that is able to provide answer to the needs of the education system. It serves as an attempt to instill intelligence in thinking, appreciation in the form of attitudes and habitual practice in the form of actions that are adjusted to moral values in society (Riadi, 2016).Character education is a cultural tool for the society to transmit its value system to the next generation. In addition to the society, family and school are the dominant institutions that are responsible in instilling this value system to the next generation (Dora Ho, 2008). In a nutshell, character education can be considered as a national movement creating schools that foster ethical, responsible and caring young people by modelling and teaching good character through universal example.

Our education system faces many challenges in its implementation. One of the challenges is that many students committed negative behaviors both in school and in their society. This shows that that there is impairment of character in adolescent including students (Karim, 2016). To make the matter worse, some students no longer feel regret or desire to improve themselves in terms of their behaviors. They assume that this mistake is a natural thing so that this leads them to avoid responsibility to carry out good behavior in their society (Göthberg, 2019). It is not an easy task to instil good character and behaviors for students. Good character is not formed automatically but it is developed overtime through a sustained process of teaching, example provision and ample practice (Pala, 2011).

In education field in Indonesia, there are still cases of fraud both committed by students and carried out in a structured manner by school residents especially principals and teachers who teach (Azmi and Kusaeri, 2017). This dishonest behavior has been proven when there was experiment to provide canteen where it was not kept to test buyers' honesty. The items were lost due to the dishonest from buying students (Ferdiawan \& Putra, 2013). Other examples of dishonest behaviors from students have tarnished education and school reputation in Indonesia. Therefore, that the issue of character education remains important and needs to be responded quickly by educational institutions. An optimal effort to implement character education may contribute to the development of students' character (Grosseck, G., 2011). In order to implement character education, all parties should manage their effort to carry out this mission. They include school principals, teachers, administrative staff, janitors, canteen guards and especially the parents at home. They should collaborate to handle the responsibility to deliver character education for the young generation (Dunlap \& Dunlap, 2017),

Madrasah as an Islamic educational institutions (Mansir, F., \& Purnomo, 2020), aims to connect the good values of the old system to something new from the science of technology and economics that are beneficial to the life of mankind. They feature the contents in terms of curriculum. Their curriculum generally have one thing in common with the education in the pesantren (Islamic Boarding School) and they usually complement it with general knowledge (Nashir, 2013). One of the madrasah institutions in Palembang is MAN (Madrasah Aliyah 
Negeri/State Islamic Senior High School) 3 Palembang. It is categorized as an educational institution with the distinctive characteristics of Islam. The school doesn't allow its students to commit such negative behavior. However, there are some students who were still carrying out negative behavior. The madrasah is expected to play important role in managing students' moral by giving them an understanding of the negative impact of the bad behavior. Studies reported that bad behaviors are influenced by the mass media which almost dominates the daily lives of student (Zlatković, B., \& Mišića, 2012).

MAN 3 Palembang realizes the importance of character building for its students. The madrasah has dormitory as the place to build the character of students. Using the system of boarding school, the madrasah designs character education as the core mission to accomplish. The madrasah and pesantren have the responsibility to build students' character to achieve the expected educational goals (Thahir, 2016). Madrasah and pesantren offer many advantages if they apply boarding school system in education since students not only learn constructively, but also affective and psychomotor aspects (Sholikhun, 2018). In boarding school, activities are basically inseparable from the development of students' cognitive, psychomotor and affective aspects. It has also several strengths, weaknesses, opportunities as well as challenges in this learning system. This education system is designed to develop students' cognitive, affective and psychomotor aspects (Atmaja, 2019).

There is a little information from scholarly research investigating a new character education model applied in the madrasah with boarding school system. This study tries to fill the gap. It sought to explore the new model of character education that can shape students' attitudes, and strengthen the potential of students to be able to avoid immoral acts. It is hoped that character education is not only a theory, but it requires real action with application in various Islamic educational institutions, especially in madrasah. In international context, character education has a problem since it has not been fully actualized into the individual self of each student. Meanwhile, in the Indonesian context, education system that contain character values has not been fully applied as habits and programs in educational institutions particularly in the madrasah.

\section{METHOD}

This study applied a case study. A case study is an intensive investigation about an individual but it can also be used to investigate small social units such as families, schools, groups of youth (Crowe et al., 2011). This research is included in the category of field research based on the data sources. When it comes to data presentation technique, this study used a descriptive pattern. Data were collected using three techniques: in depth interview, participant observation, and documentation (Bogdan, 1992). Data were analyzed using the framework developed by Miles \& Hubermen (2002). They consist of data reduction, data presentation and conclusion drawing. At the data reduction stage, it focused on the character education process and the achievements obtained from character education. After the data was reduced, then they were presented in the form of a brief description, chart, relationship between categories and flowcharts. After presenting the data, the researcher drew conclusions (Huberman \& Miles, 2002).

\section{RESULTS AND DISCUSSION}

This research aimed to analyze the model of character education implementation in the madrasah in terms of its planning, implementation and evaluation. The data were collected from interviews from various elements, both teachers, coaches and those involved in this study. Interviews were conducted to gain data providing explanations and ideas for character 
education models in the madrasah. In general, there are three findings to describe: the planning, the implementation and evaluation of character education in the madrasah.

\section{The Planning of Character Education}

MAN 3 Palembang's Vision, Mission and Purpose

The madrasah has a clear vision and mission and objectives to deliver character education in its educational service. This can be seen from the vision of "noble character", the mission of "behaving according to Islam way of life" and the goal of "creating a noble academic community". This means that the madrasah's vision, mission, and goals contain values that are the basis for character education. The values that underlie the vision, mission and goals of the madrasah are the values of life that live in the midst of the community where the education unit operates. Thus, it can be concluded that character education planning is reflected in the madrasah's vision, mission and goals. In line with the madrasah' vision, mission and objectives mentioned above, the Head of the Madrasah explained that character education has been planned.

"Yes, the vision and mission of $M A N 3$ contains character education values. It is clear that morals are the same as characters. Madrasah is a place for building morals or character. In addition, MAN 3 also has a dormitory and all $X$ grade students to be required to live in the dormitory for 1 year. We hope that we are able to create students who have noble character and have good religious understanding and they can also socialize in the shade of an Islamic environment. This is that we have a commitment to educating and fostering the morals or character of students (Amrizal, Personal Communication, October 15, 2017)".

Morals or characters are the main mission of the Madrasah to implement in its educational service. In line with this, Tugino expressed in an interview:

"This has been clearly illustrated from the vision of the Madrasah which reads "Morals of Honor, Excellence and Achievement". Meanwhile, the mission of the madrasab is among others: (1) Improving Islamic human resource behavior. (2) Creating an Islamic school environment, which in the end aims to create a noble morality academic community (Tugino, Personal Communication, October 17, 2021).

The Deputy of Curriculum of the madrasah, stated:

"In formulating the vision, mission and objectives of the Madrasab Aliyah Negeri 3 Palembang, all parties were involved, such as school committees, teachers, employees, and even representatives of guardians of students who we also invite. The issue of character or morals is the main topic in the formulation of the vision of the madrasah, so that the vision of the madrasah is formulated, namely "Moral, Excellent and Achieving. Therefore, this vision must be understood by all madrasah citizens, especially teachers who are at the forefront of success in shaping the character of students. So, in teaching and learning activities, the teacher must be able to design character learning and I continue to monitor it, starting from the lesson plan to learning activities in class. In addition, our madrasah principals always socialize the vision of the madrasah in various activities such as leading ceremonies on Mondays and other activities" (Eristi, Personal Communication, October 20, 2021).

The Deputy for Student Affairs at Madrasah Aliyah Negeri Palembang also confirmed the statement from the Deputy for Curriculum. He revealed:

"In Madrasah Aliyah Negeri 3 Palembang, we have a religious program that refers to the vision, mission and goals of the madrasah, such as religious activities such as dhuba prayer, religious lectures, reading the Quran every morning before starting study bours, visiting fellow students who are sick, visiting to orphanages and celebrating Ramadan in Islamic boarding schools, (Amrizal, Personal Communication, October 15, 2017)." 
Based on the information of the Head of the Madrasah, Deputy Curriculum and Student Assistant at Madrasah, it shows that the vision, mission and objectives of the madrasah are noble morals (positive character). Therefore, the vision, mission and objectives must be implemented in all activities including teaching and learning activities. To realize and achieve the vision, mission and objectives of the madrasah, the teachers' (educator) understanding of the vision, mission, and goals is very important. Character education at the Madrasah is carried out well in teaching and learning activities, especially the Islamic religious education subject group and religious extracurricular activities. Madrasah vision is implemented in these activities. The teacher of SKI (Sejarah Kebudayaan Islam/Islamic Civilization and History), stated:

"I've been teaching here for seven years, Alhamdulillah, we really know (understand the vision, mission and goals of MAN 3 Palembang). Because the vision, mission and objectives are always conveyed (socialized) by the head of the madrasah to the teachers during meetings, when the head of the madrasah is the supervisor of the ceremony, it is always conveyed. As an SKI teacher, we apply it in learning activities. For example, in every meeting I always insert character values, for example in the material "The Social Condition of the Quraish Society Before Islam" the character values of the love of science (Mukhlish, Personal Communication, July 7, 2017)."

This was confirmed by a statement from the teacher of Aqidab Akblak subject. She revealed:

"All the activities in the madrasah are derived from the vision, mission and objectives of the madrasah, such as teaching and learning activities, programs, extracurricular activities, madrasah environment, madrasah culture and so on. We can't run away from the vision, mission and goals, namely "baving a noble character". There are teaching and learning activities, for example, you have to insert character values (morals), after they study here, they are not only smart, but they also have a good attitude (character) (Zuhriah, Personal Communication, July 8, 2017).”

The teacher of Al-Qur'an and Hadith subject. He explained:

"We are very concerned with morals or character. So, I teach lesson very firmly with students. If there are students who are late, I punish them, another example, my students are punished for not bringing the Quran. Every time I explain the verse or explain the translation, I always insert character values. For example, students must be honest, disciplined, enthusiastic. Students should maintain their ablution and so on." (Somah, Personal Communication, August 10, 2019)."

Based on the results of the interviews above, it can be seen that the teachers' understanding toward the vision, mission and goals is very good. This is proven by the teacher being able to insert character values in teaching and learning activities. In addition, the vision, mission and goals are used as role models or foundations in various matters such as preparing learning tools, compiling programs for extracurricular activities and all other activities.

In addition, the teachers at the madrasah have a good understanding of the vision, mission and objectives of the madrasah. This is evidenced by the addition or modification of learning achievement indicators, learning activities and assessment techniques. Other things can be seen from the teachers' commitment to provide good behavior examples to students. For example, the way the teacher talks, dresses, delivers material, expresses their tolerant and various attitude. The goal is to build the child's or student's personality into a good human being, a member of society and a good citizen.

The madrasah has designed clear vision and mission to deliver character education. The values raised in the vision, mission, and goals of the madrasah are religious values, cleanliness and health, care, achievement, love of reading, and cooperation and assistance (Gkoltsiou, A., \& Mougiakou, 2021). It goes without saying that vision, Mission and Goals are role models to realize and brought into action in the school. It must be used as a basis for teachers to think, behave and act to deliver character education in their school (Was et al., 2006). The prophet 
Muhammad has set the example, apart from being an apostle, he also served as an educator, counselor, politician, leader and statesman. This appears in his preaching, when he is traveling or visiting associations with various people from various nations, tribes, religions, languages, traditions and cultures, with various characters and nature. He can communicate effectively with people dealing in a language appropriate to the nation (Mansir, 2019).

\section{The Madrasah's Facility and Infrastructure}

The Madrasah has some facilities like language laboratory; science Laboratory; computer lab; Workshops and Production Units; mosque; Student dormitories; joint learning resource center; multipurpose building; cooperation unit for student. It has complete infrastructure and the conditions are very good. This indicates that the implementation of character education in the Madrasah is supported by complete infrastructure with very good conditions.

Facilities and infrastructure are absolutely necessary for the achievement of the goals of the institution and the teaching and learning process. The facilities and infrastructure highly support the smooth implementation of all activities in the educational institution. They also affect the development of the quality and quantity of an educational institution. Facilities and infrastructure are benchmarks for the quality of madrasahs or educational institutions. Without the existence of facilities and infrastructure in good educational institutions, the process of education, learning and character education of students absolutely can't run optimally. Educational facilities and infrastructure are important instruments in education and become one of the eight national education standards. The completeness of educational facilities and infrastructure is an attraction for prospective students. Educational facilities and infrastructure are very important materials. The facilities and infrastructure in the madrasah: language laboratory, multi-media learning facilities are academic facilities that are functioned optimally and efficiently. This laboratory has a very positive effect on improving the quality of learning. Natural science laboratory consists of physics, chemistry and biology laboratories that are a means of proof that is directly proven by students to support the theories that have been submitted and are equipped with adequate tools and materials for practicum. Computer laboratory, the current multi-media facility is a very dominant factor in the fast-paced and practical development of technology. Workshops and production units that means of skills to support the quality of graduates who are ready to work and skilled, there are several workshops: skills in fashion, welding skills, electronics skills. Health clinic that a supporting factor in creating healthy and intelligent students. It also supports the Palembang Healthy Local Government program in 2008 and the National Healthy Indonesia Program in 2010. This Health Clinic has two nurses and one doctor as the person in charge of the clinic. Mosque, that functional means of religion as an alternative in creating Islamic students (generation) who always actualize ethics and morals in accordance with the morals of the akblakul karimah. Students' dormitory, students of class X in the madrasah are required to live in a dormitory located within the madrasah environment. Students grade X of the madrasah are required to live in a dormitory located in the madrasah. Center for collaborative learning resources, it is a service facility laboratory for improving the skills and professional quality of educators and administrators of madrasah aliyah and other educational staff in supporting the role of the madrasah as a madrasah model. Multipurpose building, that supporting facilities in streamlining extracurricular organizational programs in madrasahs, both directly or indirectly. This facility can also function as a means of community activities. Students' cooperation unit, it is a laboratory of economics and social sciences for students in direct economic endeavors. They can practice how to buy and sell, do business, work in an Islamic way to meet the needs of life at a later time. 
Deputy for facility at the madrasah explained:

"The facilities and infrastructure at the madrasah are very complete. We have laboratories, mosques, dormitories, multipurpose buildings, cooperatives and so on. With these facilities and infrastructure, the madrasah is well supported. It has a great support to carry out smooth implementation of all activities at the madrasah. With good infrastructure, teachers can freely determine what media, methods, strategies and even learning models they want to apply, including in this case the character building of students at the madrasah. Character education is the goal of the madrasah. Therefore, we will continue to improve the facilities and infrastructure at madrasah aliyah Negeri 3 Palembang so that our teachers can develop character learning (Saliasna, Personal Communication, July 15, 2017). It is clear that those facilities were deployed to deliver character education at the madrasah.

\section{Classroom Management}

Classroom is very important to pay attention to, such as spatial arrangement, placement of learning tools and seating arrangements. It can reflect the people who occupy it. A clean and attractive classroom will create a comfortable and conducive learning environment. Clean class conditions are a form of habituation for students to always maintain personal hygiene and their environment. This serves an application of their sense of responsibility to maintain cleanliness, comfort and order of the surrounding environment.

This was confirmed by fiqh teacher:

"In our class, we arrange the rooms, arrange the learning tools and arrange the proper seating, and always apply the habit of disposing of trash in its place not in the classroom. We instill them in order to always maintain cleanliness anywhere, both in the classroom or outside the classroom because a good class is a clean class (Nurhijah, Personal Communication, July 11, 2021)."

Class will be a very interesting place if it is managed properly. One of its ways is the seat of students. Thus, children do not get bored when learning in class. Besides seating and maintaining cleanliness, the madrasah also puts up decorations on the classroom walls. The decorations are the work of students from Indonesian hero figures. The work of students is also a form of motivation for students. Class is also one of the most important components in preparing learning tools so that later teachers (educators) can determine and develop character learning activities.

\section{The Madrasah Environment Management}

Based on the observation, this study found that the madrasah managed the environment well. It arranged a comfortable garden and slogans outside the classroom such as "keep clean", "you are in an islamic environment", "dress modestly", "pray before you are prayed"," smile, give greeting, be polite" and so forth. It is intended that the scenery through creative images makes students recognize simple characters in everyday life. Cleanliness in the madrasah environment is also given great attention because apart from the madrasah class, it also carries out learning outside the classroom such as in the madrasah yard and in front of the class to create innovative learning.

This madrasah environment management made children feel happy and are not bored. In setting the environment outside the classroom, it is also very necessary to be arranged in such a way as to create a varied and not boring environment for students. Therefore, it can form character which is expected not only in the classroom, but outside the classroom is also expected to form the character of students. One of which is by structuring the environment outside the classroom. The school should deploy efforts to serve as the dominant dominant institutions that are responsible in instilling this character education to the children (Dora Ho, 2008). The classroom and madrasah environment should be clean in order to serve as an attempt to instill intelligence in thinking, appreciation in the form of attitudes and habitual practice in the form of actions that are adjusted to moral values in society (Riadi, 2016) 


\section{Implementation of Character Education in Learning Activities}

Learning activities consist of preliminary activities, core activities, and closing activities. They are conducted to make students practice the targeted character values. As it has been explained that the principles of contextual teaching and learning are recommended to be applied to all stages of learning because these learning principles can simultaneously facilitate the internalization of values. In addition, the behavior of teachers throughout the learning process must be a model for the implementation of values for students.

The implementation of Islamic Education learning at the madrasah was systematically structured. This is shown by the learning implementation plan that has been designed to refer to character education. It is listed in point first core competence that aims to appreciate and practice the religious teachings of the students. This shows the existence of a character education process so that students become religious. Second core competence has included more than the implementation of character education in social terms, such as developing honest behavior, discipline, responsibility, caring, polite, environmentally friendly, mutual cooperation, cooperation, peace-loving. They should be responsive and proactive and showing an attitude as part of the solution to various problems of the nation in interacting effectively with the social and natural environment and in placing themselves as a reflection of the nation. It shows that the concept of Islamic Education learning has been directed so that students have characters who are good at getting along in life and discipline in everyday life.

It is also explained in the lesson plan point third core competence. It contains understanding and applying factual, conceptual, procedural knowledge in science, technology, arts, culture and humanities with insights into humanity, nationality, state and civilization related to the phenomenon of solving events and applying procedural knowledge in the field. It is also specific studies in accordance with their talents and interests to solve problems, with the hope that character education makes students smart people. Fourth core competence in the lesson plan of Islamic religious education subject group (Quran and Hadith, Aqidah and Akblak, fiqh and Islamic Civilization, and History) contains processing, reasoning, and presenting in the realm of concrete and abstract realms related to the development of what they learn in school independently and able to use methods according to scientific principles with the aim that students have good character skills.

Based on the observation, this study found that the teacher of Aqidah and Akhlak, conducted several stages of learning in the classroom. The teacher started by saying greetings. Students read the short Quran and then the teacher opened the beginning of teaching and learning activities. The implementation took five stages: observing, the teacher divided the class into three groups and divided three different topics. He allowed students to read and observe the material according to the theme determined with the aim of each group being able to act out the topic. Asking, when discussion faced problems, students were invited to ask other friends or ask directly to the teacher. Exploring or collecting data or experimenting. Each group discussed how to act out the topic, started to divide the characters and how to express the topic in the role. Associating, each student was asked to relate the material being discussed with everyday life and communicating. Each group demonstrated and presented each role in front of the other groups according to the topic.

After the implementation stage, an evaluation was carried out, in which some of the deficiencies that exist in the teaching and learning process will later be replaced or corrected again. The evaluation at this stage was applied using an assessment instrument after the teaching and learning process ended. As for the data obtained from in-depth interviews and direct observation, it can be seen that character education at the madrasah is a shared responsibility, therefore, the head of the madrasah instructed all relevant parties, especially 
teachers to implement character education in every learning activity, both inside and outside the classroom. The following are the results of the interview with the head of the:

"If we look at the condition, currently the problem in the world of education that often occurs is that students begin to lose their identity, in which the character values in the students themselves do not obtain more attention from the educators or educational institutions concerned. As a result, there are so many incidents that arise that between general school students and students in madrasah. The difference is evident in terms of their behavior, relationships, environment and so on. Madrasah Aliyah Negeri 3 Palembang strives for students to have a different character from other schools, as we will later strive for our students to have character, practice religious teachings, have religious knowledge, and have an understanding of science. Therefore, in addition to science, Islamic Education plays an important role as a foundation for character learning for students in madrasabs" (Tugino, Personal Communication, October 17, 2021).

In line with the statements above, the deputy of curriculum representative argued:

"Students have to get used to that character, sir, especially if we see that children today have strange interactions. As educators, I must be worried, so that in this madrasah I hope they will get good moral education so that they become good individuals. Basically, the principal of madrasah has instructed all the teachers, especially the Islamic Education teacher" (Eristi, Personal Communication, October 17, 2021).

The teacher who taught fiqh at the madrasah also emphasized the following:

"In my opinion, teaching character education, especially in madrasah has certain difficulties. Yet, if I pay attention to the students in the madrasah, Alhamdulillab they are exbibiting attitude of ta'drim (polite) to the teacher, they are polite and friendly. On the other hand, what I apply when the learning process of teaching Islamic Education in the classroom has familiarized them to always be disciplined in learning, do their assignments well. I ask them to be disciplined and to always practice what they have got from teaching and learning activities in class into the application of everyday life" (Nurhijah, Personal Communication, July 10, 2021).

Islamic religious education subject in this case prepares students to believe, understand, and practice the teachings of the Islamic religion through predetermined guidance, teaching or training activities to achieve the goals set by the madrasah. In addition, Islamic Education teach students to have good character in life. In line with this, the teacher of Aqidab and Akblak at the madrasah revealed:

"In terms of content, the Islamic Education subject is filled with character, sir, as in the subject of aqidah morals about faith, manners, religion, mutual cooperation, discipline, responsibility, tolerance, love for the country and so on. Now we observe how these students are, whether it is in accordance with the daily behavior or not, that's what is called the character habituation process. In this madrasah, in teaching and learning activities of Islamic Education, I familiarize students to learn not only to understand the subject matter, but also the essence must be applied gradually by students (Nurhijah, Personal Communication, July 10, 2021)."

Another Islamic Education teacher stated:

"As one of the Islamic Education teachers in this madrasah, I think the weight of the responsibility for the good and the bad behavior of students is a relatively beavy task. If the students are naughty, we are the ones who are in trouble, but if the students are good, we are the ones who are happy. Thus, in this case, the teacher must really put more effort into fostering the character of students. For example, in the case of teaching and learning activities in class, the character must be internalized in Islamic Education subjects because the basic character itself is the source of the Quran and hadith, so it is clear that Islamic Education can't separate these characters, especially Aqidah and Akblak and Quran and hadith as the application of the character itself' (Mariana, Personal Communication, July 16, 2021).

Base on the results of the interviews mentioned above, conclusions can be drawn about character education in Islamic Education subjects at Madrasah Aliyah Negeri 3 Palembang, such as the importance of the role of teachers as intellectual educators and character educators 
for their students, teachers teach students material according to the curriculum by using the process good and effective Islamic Education subject learning without neglecting the essence of the character values contained in Islamic Education subjects to be applied by students in their lives and to achieve the expected goals.

Based on the interviews above, it can be seen that the application of character education is important for students in madrasah. Even in the classroom, teachers guided their students in learning, making friends, living together and developing their good daily behavior, (Pane \& Patriana, 2016). Those learning activities should be designed to develop students' cognitive, affective and psychomotor aspects (Atmaja, 2019). They should be applied in boarding school system in education to facilitate students to learn constructively for their affective and psychomotor aspects (Sholikhun, 2018).

\section{Implementation of Character education in Teaching and Learning at the Madrasah}

In this section, the study describes the findings on the implementation of character education in the teaching and learning activities at the madrasah.

As explained earlier, the principles of contextual teaching and learning are suggested to be applied to all stages of learning because these learning principles can simultaneously facilitate the internalization of values. In addition, the behavior of educators throughout the learning process must be a model of the implementation of values for students. To implement character education in learning activities, there are three stages to take into consideration.

a) Preliminary Activity

Based on the observation and interview, this study found that there were efforts conducted by teachers of Madrasah to teach character education. The efforts were aimed to introduce values, build awareness of values, and help internalize values or characters in preliminary activities are that teachers arrive on time (disciplined character); say greetings to students kindly while entering the classroom (polite and caring character); praying before opening the lesson (religious character); checking the presence of students (disciplined and diligent character); praying for students who are absent because of illness or because of other obstacles (religious character, care); ensuring that every student arrives on time (disciplined character); reprimanding students who are late politely (disciplined character, polite and caring); linking material/competencies to be studied with character; by referring to the syllabus, lesson plans, and teaching materials. In addition, this study found that teachers began the learning by reading prayers led by the class leader. Furthermore, teacher and students recited basmalah after reading prayers and before starting the learning activities in class. This was done so that students had religious character.

This study found that during teaching and learning activities, teachers always asked the condition of their students and their readiness in conducting the learning activity. Teachers as facilitators of teaching and learning activities, were expected to be able to understand the learning difficulties of students whether by listening to students' complaints or by communicating with them. Teachers did not keep their distance from students. This was implemented so that students had a communicative character. In teaching and learning activities, the educator checked the presence of students. Thus, students needed to have a disciplined character because currently there are many cases that are shown by Indonesian students. The examples included being late for school, skipping class, not pursuing homework, and others. Therefore, it needs to make innovation and motivation that can prevent these actions.

b) Core activity

Based on learning process in 2013 curriculum, all education levels apply scientific approach. The steps of a scientific approach, in the learning process, include exploring information through observation, asking questions, experimenting, then processing data or 
information, presenting data or information. They were followed by analyzing, reasoning, then concluding, and creating steps. Scientific approach is popularly known with the term $5 \mathrm{M}$ is to observe, ask, explore, associate and communicate.

First, observation. In learning and teaching activity, teachers asked students to read their resumes. Teachers trained students to learn. Then, students felt that everything they did became an encouragement or motivation to themselves to master the material taught material. This is implemented so that students have a character who likes to read such as reading resume material taught previously. In addition, in teaching and learning activities on Quran and Hadith subjects, teachers asked students to identify about QS. Al-Baqarah/2:30-32 and QS. Az-Zariyat/51:56. Given this circumstance, teachers trained students to have critical characters, such as the ability to analyze ideas or ideas logically, reflective, systematically and productively to help make, evaluate and make decisions about what is believed or will be done. Thus, it is successful in solving a problem faced. (Character values taught include hard work, independent and likes to read).

Second, asking questions. In teaching and learning process, teachers gave some questions for students to answer. They gave one point if the answer was wrong, and awarded two points if the answer was correct. When the answer was incorrect, the student could ask other student to answer the question correctly. Thus, the students had the character of curiosity. Students needed to make strategies that can foster the courage of students in asking. Teachers mentioned the names of certain students who are relatively active and enthusiastic in participating in learning. For example, when the teaching and learning process took place followed by the explanation to students "If A learns to works hard, you can be a champion" to establish an emotional relationship between teachers and students warmly. Thus, students had the character to appreciate the value of achievement, which is to value whatever every effort is made by their classmates. Whether it is in the form of providing responses, suggestions, criticisms and answers from everything asked by the teacher. In this opportunity the character values taught included curiosity and independence.

Third, exploration. In teaching and learning process of Aqidah and morals subject, the teacher asked students to make groups. Students were divided into several groups and given the task to discuss and respond to the praiseworthy moral films of Muslim youth in Indonesia and Palestine in accordance with predetermined themes. From this activity, the students had a creative character by digging and gathering information from various sources through various means. In the same vein, the learning of figh subject featured similar things. Teacher emphasized all students to help each other in answering questions. This is to make students to have the character of tolerance, such as respect and respect when other groups disagree. In addition, the attitude of tolerance in a person will cause affection in them so that the sense of brotherhood towards others will be even greater. With a high sense of brotherhood, in general it avoided disunity or dissent. In this occasion, the character values taught included honest, polite, respectful, independent and friendly.

Fourth, association. In learning and teaching process in Quran and Hadith subjects, the teacher asked students to conclude Question and answer in literature review and other information about the review of hadith in terms of quantity. This is conducted so that students had an independent character. Because students were required to find the linkage of one information with other information, they found patterns from the linkage of that information. In addition, in the subjects of the Islamic Morals, it can be seen that teacher asks students to take turns giving each group participants the results of the discussion while other group students showed/listened and respond. Therefore, students had the character of tolerance. It is seen when other groups convey the results of the discussions they were 
working on, other groups listened to or respect the opinions of other groups. In this occasion, the character values taught included hard work, discipline and honest.

Fifth, communication. Based on observation data in learning and teaching activities, a teacher gave reward to students who could answer the question such as applause and an award-winning sentence with the expressions like "good" and a warm smile. By giving an award, students felt that everything they did became an encouragement or motivation to themselves to answer the challenges of educators in the future. On the one hand, what educators did have provided role models for students about how to value the achievements of others and motivate students to excel. It made students to have the character to value achievement, which is to value every effort made by their classmates. Whether it is in the form of providing responses, suggestions, criticisms and answers from everything asked by the educator (character values taught included tolerance, responsibility, critical and logical).

In teaching and learning activities, it appears that teachers ask students to read their resumes, (Juchem et al., 2020). Thus, educators train students to be serious in learning. Students will feel that everything they do is a support or motivation for themselves to master the material being taught. This is conducted to make students to have a character who likes reading, namely reading the resume of previously taught material (Mariyana, 2014). In addition, in teaching and learning activities in the subject of Quran and Hadith, teachers ask students to identify QS. Al-Baqarah/2:30-32 and QS. Az-Zariyat/51:56. Teachers train students to have a critical character, such as the ability to analyze ideas or ideas logically, reflectively, systematically and productively to help make, evaluate and make decisions about what is believed or will be conducted. Thus, they are successful in solving problems encountered (Mariyana, 2014).

This study found that in Asking activity, there are two advantages. First, giving opportunities widely for students to ask questions about what has been seen, listened to, read or observed. (Be creative and independent character). Second, developing creativity, the ability to formulate questions to form critical thoughts necessary for intelligent life and lifelong learning.

In the teaching and learning process, it is seen that teachers give questions to students to be answered. Teachers gave a point if the answer was wrong, and gave two points if the answer was correct. When the answer was not correct, students could ask other students to seek help to answer the question correctly. Therefore, students are taught to have a character of curiosity, and students need to make strategies that can foster the courage of students in asking questions (Mariyana, 2014). During the teaching and learning activities, a teacher mentioned the names of certain students who were relatively active and enthusiastic in participating in the learning process. For example, when the teaching and learning process took place, it is followed by the mention of "if you learn and work hard, you can be a champion". It is to establish a warm emotional relationship between educators and students. Thus, students have the character of appreciating achievement, such as appreciating whatever efforts are made by their classmates. It is in the form of providing responses, suggestions, criticism or answers to every question asked by the educator (Mariyana, 2014).

When it comes to exploration step, this study found that it offers two advantages. First, digging and collecting information from various sources in various ways. In this opportunity, creative character is taught. Second, respecting the opinions of others, the ability to communicate, apply the ability to collect information in various ways that are learned, develop learning habits and lifelong learning. In this opportunity, the character of honest, polite, respectful, self-sufficient and friendly are taught.

When the teaching and learning process took place in the Aqidah and Akblak subject, teachers arranged students into groups. Students were divided into several groups and given 
the task of discussion and responses to films of praiseworthy Islamic youth in Indonesia and Palestine according to predetermined themes. Thus, students are taught to have a creative character, by exploring and collecting information from various sources in various ways (Mariyana, 2014).

The character education is also applied in the figh subject. Teachers emphasized all students to help each other in answering questions. This enabled students to have a character of tolerance, such as appreciating and respecting when other groups have different opinions. Besides, tolerance in a person will create a sense of affection in him/her. Thus, the sense of brotherhood towards others will be even greater. With a high sense of brotherhood, in general, divisions or differences of opinion are avoided (Mariyana, 2014).

In relation with the steps of Association in scientific approach, this study found that there are two advantages to offer. First, finding relation of one information with other information, find patterns of related information. In this opportunity, hardworking, creative and independent character are taught. Second, ability to apply procedures and the ability to think inductively and deductively in concluding. In this opportunity, hard work, discipline and honest character are taught.

In the teaching and learning process in the subject of Quran and Hadith, it is seen that the teacher asked students to conclude the Q\&A literature review and other information about reviewing hadith in terms of quantity. This enabled students to have an independent character. Because students were required to find the linkages of one information with other information, find patterns from the linkages of that information (Mariyana, 2014). In addition, in the Akidah and Akblak subject, it is seen that teachers asked students in turn, each group student to convey the results of the discussion while other group students show or listen and provide responses. In this case, it enabled students have a tolerance character. It can be seen that when other groups presented the results of the discussions they were working on, the other groups listened to or respect the opinions of the other groups (Mariyana, 2014).

When it comes to the step of Communication, this study found that there are two advantages to offer. First, writing down or telling what is found in information seeking activities. In this opportunity, independent character and responsibility are taught. Second, expressing opinions briefly and clearly, and developing good and correct language skills. In this opportunity, the character of honest, tolerance, responsible, critical and logic are taught.

Based on the observation, this study found that teacher gave appreciation to students who could answer questions by clapping and sentencing that contain appreciation, namely "good" and warm smiles. By giving an award/appreciation for students who could answer questions or assignments, students felt that everything they do is an encouragement or motivation for themselves to answer challenges from educators in the future. On the one hand, what teaches do to provide examples to students on how to appreciate the achievements of others and motivate students to achieve. This enables students to have the character of appreciating achievement, such as appreciating whatever efforts are made by their classmates, whether it is in the form of providing responses, suggestions, criticism or answers to every question asked by the teacher (Mariyana, 2014).

In teaching and learning activities, this study found that teacher asked students to read their resumes. Thus, teacher train students to be serious in learning. Next, students would feel that everything they do is a support or motivation to themselves to master the material being taught. This enabled students to have a character who likes reading, namely reading the resume of previously taught material. In the subject of Aqidah and Akblak, it is known that teacher asked students to make conclusions orally (randomly selected). This enabled students to have good character, for example when teachers asked students to make conclusions after 
the teaching and learning process takes place. Hence, students were required to do or convey something in accordance with reality and logic (Mariyana, 2014).

In terms of learning media, teacher used a variety of media such as pictures, posters, maps, graphics, and even in focus. As in the subject of figh, it can be seen that teachers provide image media in the form of images of the $K a^{\prime} b a b$ as material for students to observe. This can foster the power of thought of students with some indicators among them who asked questions, gave responses and rebuttals. This media was conducted to help students have a creative character, care about the environment and a character of curiosity. To develop a creative character, teachers gave a challenging task to the emergence of new works, both authentic and modified. The work/handicraft was in the form of traditional houses, mosques, and madrasah buildings made from ice cream sticks. This was confirmed by fiqh teacher:

"Making miniature houses of worship such as mosques or prayer rooms from used ice cream sticks is intended to train children's abilities. This also sharpens students' talents so that they are more creative in processing used goods that are no longer used by us. Besides, making miniature houses of worship using ice cream sticks can foster a sense of love for houses of worship and a sense of caring for students about garbage in the surrounding environment, especially in MAN 3. It also aims to instill the character of students' curiosity (Nurhijah, Personal Communication, 2018).

The madrasah and pesantren have the responsibility design well the teaching and learning activities to build students' character to achieve the expected educational goals (Thahir, 2016). The education system in the pesantren (Islamic Boarding School) should be able to combine both Islamic religious education and general knowledge to ensure the charcter education development on the part of students (Nashir, 2013). Madrasah as an Islamic educational institutions are expected to be able to connect the good values of the old system from the religion and the new things from the advancement of science and technology (Mansir, \& Purnomo, 2020). There many ways to deliver learning material. The use of film to deliver learning materials in the classroom is strongly suggested (Kim, 2015). Character education can be integrated in learning process for students. It can be designed in learning activities that have preliminary, core and closing activities. They are implemented so that students practice the targeted character values (Bailey, Tettegah, \& Bradley, 2006).

\section{The Evaluation of Character Education}

The evaluation of character education was carried out at the madrasah. There were some techniques to measure the character education implementation. First, by observing directly the learning and teaching activities such as evaluating the implementation of character education in form of the teacher's task. The form of report were stated in a qualitative statement like "has not been seen" (if the student has not shown the initial signs of behavior stated in the indicator), "start to be seen" (if the student has shown the initial signs of the behavior stated in the indicator but has not been consistent), "starts to develop" (if the student has shown various signs of behavior in the indicator and starts to be consistent), civilizing (if the student continues to show the behavior expressed in the indicator consistently).

The second technique to evaluate character education is point collecting book. The function of this book is to control every student's behavior, liaison between the school and parents or guardians of students and as a sign for students to be able to obey and not violate them (Kim, Choe, \& Kaufman, 2019). It serves as code of conduct book containing the types of violations and points that have been determined in accordance with the lightness or severity of the violations committed by students. As an amplifier on the last page of the code of conduct book, there is a statement that must be signed and stamped with a stamp as a consequence of students to be able to obey the rules that have been set and are willing to be excluded from madrasahs when it reaches a maximum point of 100 points. This rule forces 
student to obey the rules of madrasahs because it is designed to make sure that students are in the position to develop their good character

Third technique applied to measure character education is monitoring. Monitoring process is conducted by madrasah principal with a number of ways to observe the learning process in class directly by paying attention to aspects of the implementation of character education. The implementation can be in the form of participating in habituation activities such as fast pesantren camp (pesantren kilat), religious lectures, etc. The monitoring was also applied in the form of conducting interviews with teachers, students, employees or people parents related to the condition of the implementation of character education and the role of all parties in the madrasah. It was also deployed by observing activities in the madrasah without being known directly by the object of observation or the school community and conducting discussions and monitoring with each teacher related to the document of student violations of the code of conduct as well as the progress in implementing character education in classrooms.

This was emphasized by fiqh teacher:

"The monitoring is applied to evaluate the character because the character of student behavior changes every day. Therefore, we the Islamic Education subject teachers at the madrasah evaluate the character education. Evaluation of character learning in the Islamic Education subject group at Madrasah Aliyah Negeri 3 Palembang is conducted to determine the extent to which students 'ability to master Islamic Education material, especially in the development of students' character. It is carried out with the results of observations and assignment reports by the teacher. We do with direct observation while teaching and learning. In the lesson plan, in the evaluation point, there is a way to assess attitudes. In addition, there is a liaison book from madrasah to parents to control every student's behavior called a point book, that contains points of violation of student points in the accumulation of 100 points, so the student get warning letter (Faris, Personal Communication, July 17, 2017).”

Base on the results of the interview above, the form of character education evaluation that was carried out when learning in class is in the form of direct observation of the attitudes of students during learning in class, (Pavo, 2021). If there are problems related to student morals, it will be resolved together, (Grady, Iannantuoni, \& Winters, 2021). In weekly meetings, this evaluation did not only discuss student academics, but also evaluate the character of students who had problems. This was done to seek the solution in the evaluation meeting and each problem was resolved collectively. In addition to student problems regarding academic and student morals, in the evaluation, teacher problems were discussed regarding assessment, preparation of lesson plans, and others.

However, in today's context, the conversation about character education is slowly starting to recede along with the development of modern technology that befell modern humans (Toker, 2021). This concern arises as many Islamic educational institutions rarely implement real character education. So, we need a model of character education to give positive values to students through various activities at madrasah. Therefore, character education in this era is no longer appropriate only as a discourse. It is needed as a model to realize directly in the field, in this case Islamic educational institutions. In this study, various data from Scopus indexed international journals have been used as the main reference so that theories related to the research topic can provide sharp thinking construction.

Students' problem relies heavily in their poor character. The government and schools design character education in Indonesia to overcome the problem. This effort can be a solution offered to overcome various cases on the issue of students' moral decline. According to KPAI (Komisi Perlindungan Anak Indonesia/National Commission for Child Protection) stated that there were 255 cases of students brawl throughout 2013. There was an increase from the previous year of 147 cases (Basri, 2015). The number of brawl cases was only 12.9 
percent, but this year increased to 14 percent (Delvira et al., 2021). This condition is made worse because today's brawls becoming more sophisticated. The police ensured that the stabbing took place in Permata Hijau, Kebayoran Lama, South Jakarta on Saturday $(1 / 9 / 2018)$, the perpetrators and victims had made a pact on instagram before making a brawl (Martin, 2018). Studies reported that bad behaviors are influenced by the mass media which almost dominates the daily lives of student (Zlatković \& Mišića, 2012).

There are several studies reporting of the impairment of character in adolescent including students (Karim, 2016). In education field in Indonesia, there are still cases of fraud both committed by students. The issue of honesty can be tested for students. An experiment to provide canteen where it was not kept to test buyers' honesty. The items were lost due to the dishonest from buying students (Ferdiawan \& Putra, 2013). This problem should be handled carefully by the school to ensure that it would not happen again (Azmi \& Kusaeri, 2017). Psychological consultation can be implemented to help solve this problem (Aitysheva \& Jumageldinov, 2014) since children may exhibit complex emotional relationship in their behaviors (Warren, 2021).

Madrasah should be able to deliver character education because madrasah is one of the barometers in building the character of students. It is not an easy task to instil good character and behaviours for students in their school. Good character of students could not be formed automatically but it requires longer time through a sustained process of teaching, example provision and ample practice for their good character to establish (Pala, 2011). An optimal effort to implement character education may contribute to the development of students' character (Grosseck, 2011). The implementation of character education should be the responsibility for all parties involved in education. They should collaborate to handle the responsibility to deliver character education for the young generation (Dunlap, \& Dunlap, 2017).

This study contributes to the body of knowledge in terms of character education implementation at the madrasah context in Indonesia. It may fill the gap from the previous studies concerning the implementation of character education at the madrasah with the boarding school system. However, this study has some limitation. There are some suggestions for further study to apply broader and bigger population, to apply more robust data collection to achieve comprehensive results.

\section{CONCLUSION}

The study was aimed at investigating the implementation of character education at the madrasah. It covers the planning, the implementation and the evaluation of character education at the madrasah. In terms of planning of character education, the madrasah has included character education in the vision and mission, purpose, strategic planning, curriculum, daily, weekly programs, monthly programs and annual programs, facilities or infrastructure, and classroom environment. In addition, the lesson plan are also part of the character education planning at the madrasah. The implementation of character education in the madrasah was applied through teaching and learning activities of madrasahs which included in the stage of preliminary, core and closing activities. To evaluate character education at the madrasah, some techniques were applied namely by conducting direct observation in teaching and learning activities, recording point book, and monitoring. 


\section{BIBLIOGRAPHY}

Aitysheva, A. \& Jumageldinov, A. (2014). The Use of The Methods of Psychological Consultation in The Education Process. Procedia-Social and Behavioral Sciences.

Atmaja, S. (2019). Sistem Pembelajaran Boarding School dalam Pengembangan Aspek Kognitif, Psikomotorik dan Afektif Siswa MAN Insan Cndekia Bengkulu Tengah. AlBahtsu 4.

Azmi, S. N \& Kusaeri. K. (2017). Menelusuri Akar Masalah Kecurangan Pelaksanaan UN di MTs Kota Surabaya. Jurnal Inovasi Pendidikan 1, 1(1), 50-63. Retrieved from http://www.riset.unisma.ac.id/index.php/fkip/article/view/224

Bailey, B. P., Tettegah, S. Y., \& Bradley, T. J. (2006). Clover: Connecting Technology and Character Education using Personally-Constructed Animated Vignettes. Interacting with Computers,.

Basri, A. S. H. (2015). Fenomena Tawuran Antar Pelajar dan Intervensinya. Hisbab: Jurnal Bimbingan Konseling dan Dakwah Islam 12(1). Retrieved from http://ejournal.uinsuka.ac.id/dakwah/hisbah/article/view/976/907

Bogdan, R. \& Robert, C. (1992). Qualitative Research from Education: An Introduction to Theory and Methods. Boston.

Crowe, S., Cresswell, K., Robertson, A., Huby, G., Avery, A., \& Sheikh, A. (2011). The Case Study Approach. BMC Medical Research Methodology, 11(1), 100. https://doi.org//10.1186/1471-2288-11-100

Delvira, N., Husen, A., \& Casmana, A. R. (2021). Penyelesaian Tawuran Pelajar di Tingkat Sekolah Menengah Kejuruan. Antropocene. Jurnal Penelitian Ilmu Humaniora, 1(1), 14-20. Retrieved from https://journal.actual-insight.com/index.php/antropocene/ article/view/18

Dora Ho, C. W. (2008). Exploring the Definitions of Quality Early Childhood Programmes in A Market-Driven Context: Case Studies of Two Hong Kong Preschools. International Journal of Early Years Education, 16 (3). https://doi.org/10.1080/09669760802343915

Dunlap, R., \& Dunlap, A. (2017). Character Ethics And Interprofessional Practice: Description and Analysis. Journal of Interprofessional Education \& Practice, Vol. 7, 61-64. Retrieved from https://www.learntechlib.org/p/205178/.

Ferdiawan, E., \& Putra, W. E. (2013). Esq Education for Children Character Building based on Phylosophy of Javaness in Indonesia. Procedia-Social and Behavioral Sciences, 1096-1102. https://doi.org/10.1016/j.sbspro.2013.12.123

Gkoltsiou, A., \& Mougiakou, E. (2021). The use of Islandscape Character Assessment and Participatory Spatial SWOT Analysis to The Strategic Planning And Sustainable Development of Small Islands. Land Use Policy.

Göthberg, M. (2019). Cultivation of a Deceiver-The Emergence af a Stage Character in a Student Theatre Production. Learning, Culture and Social Interaction. 22, 100280. https://doi.org/10.1016/j.lcsi.2019.02.005

Grady, C., Iannantuoni, A., \& Winters, M. S. (2021). Influencing the Means But Not the Ends: The Role of Entertainment-Education Interventions in Development. World Development, 138, 105200. https://doi.org/10.1016/j.worlddev.2020.105200

Grosseck, G., \& H. (2011). Teacher education in 140 Characters-Microblogging Implications for Continuous Education, Training, Learning and Personal Development. Procedia-Social and Behavioral Sciences, 11. https://doi.org/160-164. 10.1016/j.sbspro.2011.01.053

Herrera-Pavo, M. Á. (2021). Collaborative Learning for Virtual Higher Education. Learning, Culture and Social Interaction, 28, 100437. https://doi.org/ 10.1016/J.LCSI.2020.100437

Huberman, M., \& Miles, M. B. (2002). The Qualitative Researcher's Companion. https://dx.doi.org/10.4135/9781412986274 
Juchem, J., Chevalier, A., Dekemele, K., \& Loccufier, M. (2020). Active Learning in Control Education: A Pocket-Size PI (D) Setup. IFAC-PapersOnLine, 17276-17281. https://doi.org/10.1016/j.ifacol.2020.12.1805

Karim, H. (2016). Pendidikan Karakter di Madrasah Ibtidaiyah. Elementary 2, (2), 45-56. Retrieved from https://e-journal.metrouniv.ac.id/index.php/elementary/article /view/pendidikan-karakter-di-madrasah-ibtidaiyah

Kim, S., Choe, I., \& Kaufman, J. C. (2019). The Development and Evaluation of The Effect of Creative Problem-Solving Program on Young Children's Creativity and Character. Thinking Skills and Creativity, 100590. https://doi.org/10.1016/j.tsc.2019.100590

Kim, D. (2015). A Study on The Class of Education That Builds Students' Character through Films-Classes at The University of Liberal Arts. Procedia-Social and Behavioral Sciences, 1529-1533. https://doi.org/10.14400/JDC.2015.13.2.309

Mansir, F., \& Purnomo, H. (2020). Islamic Education Learning Strategies Based on Multiple Intelligences in Islamic Schoo. Psikis: Jurnal Psikologi Islami, 48-57. https://doi.org/10.19109/psikis.v6i1.4011

Mansir, F. (2019). Implication of Teacher Certification on Professionalism and Welfare of 21th Century PAI Teachers. Tadrib, 5, 138-152. https://doi.org/10.19109/tadrib.v5i2.4085

Mariyana, R. (2014). Kompetensi Guru dalam Pembelajaran Berbasis Pendidikan Karakter Untuk Anak Usia Dini. Pedagogia, 12(1), 1-18. https://doi.org/10.17509/ pedagogia.v12i1.3296

Martin, S. (2018). Makin Canggib, Kelompok Pelajar Ini Janjian Tawuran Lewat Instagram, Satu Tewas. Retrieved from https://sumsel.tribunnews.com/2018/09/03/makin-canggihkelompok-pelajar-ini-janjian-tawuran-lewat-instagram-satu-tewas

Nashir, H. (2013). Pendidikan Karakter Berbasis Agama dan Budaya. Yogyakarta: Multi Presindo.

Pala, A. (2011). The need for character education. International Journal of Social Sciences and Humanity Studies, 3(2), 23-32. Retrieved from https://dergipark.org.tr /en/pub/ijsshs/issue/26222/276136

Pane, M. M., \& Patriana, R. (2016). The Significance of Environmental Contents in Character Education for Quality of Life. Procedia-Social and Behavioral Sciences, 222, 244-252. https://doi.org/10.1016/j.sbspro.2016.05.153

Riadi, A. (2016). Pendidikan Karakter di Madrasah/Sekolah. Ittihad: Jurnal Kopertais Wilayah XI Kalimantan 14(26), 1-10. http://dx.doi.org/10.18592/ittihad.v14i26.868

Sholikhun, M. (2018). Pembentukan Karakter Siswa dengan Sistem Boarding School. Wahana Islamika: Jurnal Studi Keislaman 4(1). https://doi.org/10.5281/wahanaislamika.v4i1.20

Thahir, M. (2016). The Role and Function of Islamic Boarding School an Indonesian Contest. Tawarikh 5(2). https://doi.org/10.2121/tawarikh.v5i2.574

Toker, Ş. (2021). Islamization of Teacher Education: A Critical Discourse Analysis of Turkey's "Inclusive" Education Initiative for Refugee Integration. Linguistics and Education, 63, 100923. https://doi.org/10.1016/j.linged.2021.100923

Warren, R. (2021). Exploring The Complex Emotional Relationships that Influence Children's Participation Rights in Early Childhood Education Settings. Emotion, Space and Society, 39, 100784. https://doi.org/10.1016/j.emospa.2021.100784

Was, C. A., Woltz, D. J., \& Drew, C. (2006). Evaluating Character Education Programs and Missing the Target: A Critique of Existing Research. Educational Research Review, 1, 148156. https://doi.org/10.1016/j.edurev.2006.08.001

Zlatković, B., \& Mišića, D. (2012). Teacher's Education for a More Flexible Approach to Character Analysis in Literary Creations. Procedia-Social and Behavioral Sciences, 45, 486-492. 